\title{
Cytogenetic characterization of a population of Bryconamericus aff. iheringii (Characidae, Tetragonopterinae)
}

\author{
Tânia Regina Paintner-Marques, Lucia Giuliano-Caetano and Ana Lúcia Dias \\ Universidade Estadual de Londrina, Departamento de Biologia Geral, Londrina, Paraná, Brazil
}

\begin{abstract}
A cytogenetic analysis of thirteen specimens of Bryconamericus aff. Iheringii revealed a diploid number of 52 chromosomes and a karyotype of $8 M+22 S M+10 S T+12 A$ with a fundamental number (FN) of 92. The nucleolus organizer regions (NORs) were studied by means of $\mathrm{AgNO}_{3}$ and $\mathrm{CMA}_{3}$ staining as well as by FISH using an $18 \mathrm{~S}$ rDNA probe. NORs were found to be located at the terminal position on the short arm of the submetacentric chromosome pair. C-banding showed strong telomeric and centromeric staining in the majority of the chromosomes, and a similar pattern was observed after treatment with Alul restriction enzyme
\end{abstract}

Key words: AgNOR, Alu I, Bryconamericus, C-banding, CMA 3 , rDNA 18S.

Received: July 22, 2002; accepted: March 10, 2003.

\section{Introduction}

The Characidae family is the largest group of fresh water fish in South America, containing about 170 genera and 885 species (Nelson, 1994). The large number of species that comprise the Characidae family can be grouped into different sub-families. The Tetragonopterinae subfamily in Brazil contains the most species and consists of approximately 50 genera and 400 to 500 species. Most of these fish are small in size and live in various environments. They are mostly omnivorous and also serve as food for other fish (Britski et al., 1988).

The Bryconamericus genus is one of the least diversified in the Tetragonopterinae subfamily, consisting of 30 to 40 species that are very similar and distributed among different regions of South and Central America (Géry, 1997).

Although there have been few cytogenetic studies on this group of fish, most of the species examined have been found to have a diploid number of 52 chromosomes (Portela et al., 1988; Wasko and Galetti, 1999). The variable position of nucleolus organizer regions (NORs) has been used to characterize Bryconamericus aff. iheringii as a group that has multiple NORs (Wasko et al., 1996; Wasko and Galetti, 1999; Portela-Castro, 1999).

The objective of this study was the cytogenetic characterization of a population of Bryconamericus aff. iheringii, using different treatments (AgNOR, fluorochrome chromomycin $\mathrm{A}_{3}$ and fluorescent in situ hybridization)

Send correspondence to Ana Lúcia Dias. Universidade Estadual de Londrina, CCB, Depto de Biologia Geral, 86051-970, Caixa Postal 6001, Londrina, Paraná, Brazil. E-mail: anadias@uel.br. to detect the NORs and to locate heterochromatin by $\mathrm{C}$ banding and treatment with AluI restriction enzyme.

\section{Material and Methods}

Thirteen specimens of Bryconamericus aff. iheringii ( 8 males, 4 females and 1 undetermined sex) were analyzed collected from the Água da Floresta river, part of the Tibagi river basin (Paraná, Brazil), from August 1999 to February 2001. Mitotic chromosome preparations were obtained from kidney cells, according Bertollo et al. (1978). The nucleolus organizer regions (NORs) were analysed by the Howell and Black technique (1980), and the treatment with fluorochrome chromomycin $\mathrm{A}_{3}$ followed the Schmid technique (1980). C-banding was obtained using the method described by Sumner (1972), and the standard reactions by restriction endonuclease $A l u \mathrm{I}$ were performed using the method described by Mezzanotte et al. (1983), with some modifications as proposed by Maistro (1996). Chromosome morphology was determined on the basis of arm ratio as proposed by Levan et al. (1964). Chromosomes classified as metacentric (M), submetacentric (SM) and subtelocentric (ST) were considered as biarmed. Acrocentric (A) chromosomes were considered as uniarmed.

The $18 \mathrm{~S}$ rDNA segment containing $1700 \mathrm{bp}$ of the fish Oreochromis niloticus was used for in situ hybridization and labeled with biotin-14-dATP by nick translation (Gibco cat n. 18247-015), according to the manufacturer's instructions. The hybridization technique, post-hybridization washes and visualization were carried out in a 
manner slightly modified from that reported by Heslop-Harrison et al. (1991) and Cuadrado and Jouve (1994). The slides were incubated with RNAse A $(100 \mu \mathrm{g} / \mathrm{mL}$ in $2 \mathrm{xSSC})$ in a moist chamber at $37{ }^{\circ} \mathrm{C}$, afterwards washed with $2 \mathrm{xSSC}$ and $4 \%$ paraformaldehyde at room temperature and dehydrated in ethanol series. The hybridization mixture was prepared with 50\% formamide, 20xSSC, $50 \%$ sulphate dextrane, $10 \%$ SDS, $1 \mathrm{mg} / \mathrm{mL}$ Bovine Calf Thymus DNA and approximately $100 \mathrm{ng}$ probe. $30 \mu \mathrm{L}$ of mixture was dropped per slide. The probe was predenatured at $70{ }^{\circ} \mathrm{C}$ for $10 \mathrm{~min}$ and further put in ice for $5 \mathrm{~min}$. The chromosomes and probe were denatured at $90^{\circ} \mathrm{C}$ for $10 \mathrm{~min}, 48^{\circ} \mathrm{C}$ for $10 \mathrm{~min}, 38^{\circ} \mathrm{C}$ for $10 \mathrm{~min}$, using a thermal cycler (PTC $100 \mathrm{MJ}$ Research) and further hybridized overnight at $37^{\circ} \mathrm{C}$ in a moist chamber. Post-hybridization washes were carried out at $42{ }^{\circ} \mathrm{C}$ in a shaker (2xSSC, 20\% formamide/0.1xSSC, $0.1 \times \mathrm{xSC}, 2 \mathrm{xSSC}$, $4 \mathrm{xSSC} / 0.2 \%$ Tween 20) for 5 min each. Hybridization was detected with avidin-FITC conjugate. The chromosomes were counterstained with $1 \mu \mathrm{L}(50 \mu \mathrm{g} / \mathrm{mL})$ propidium iodide, and slides were mounted in $25 \mu \mathrm{L}$ Vectashield antifade H1000 (Vector). Chromosomal images were obtained with Fuji color film, ISO 100.

\section{Results and Discussion}

The Bryconamericus aff. iheringii samples studied had a diploid number of 52 chromosomes distributed as $8 \mathrm{M}+22 \mathrm{SM}+10 \mathrm{ST}+12 \mathrm{~A}$ with a fundamental number $(\mathrm{FN})$ of 92, for both males and females (Figure 1). The same diploid number had also been found in the River Keller Bryconamericus aff. iheringii population from the River Ivaí basin (PR) (Portela-Castro, 1999). However, three different cytotypes were detected in the latter population:
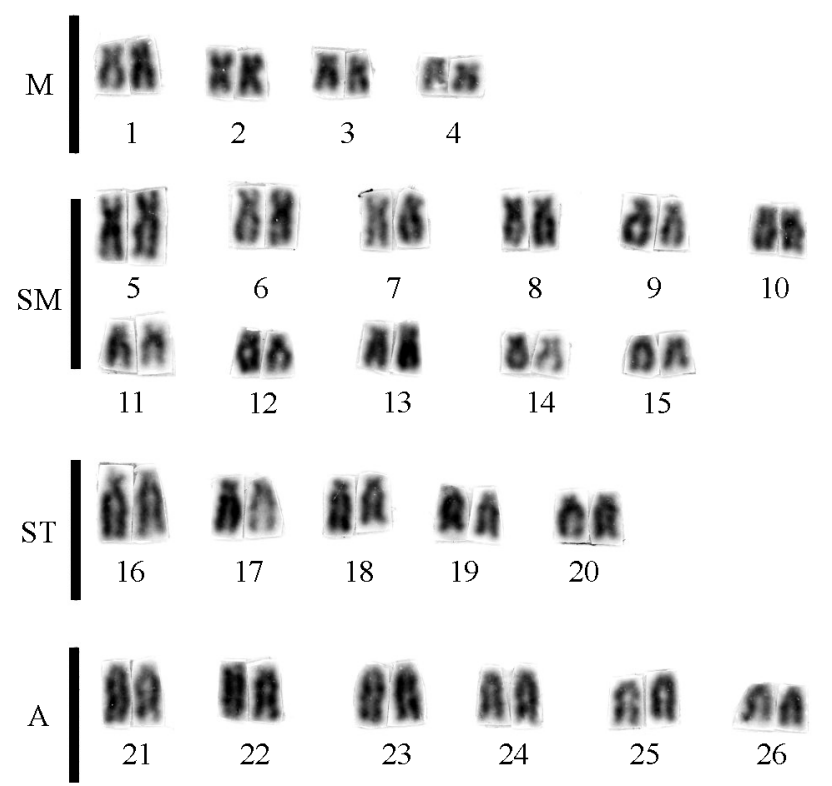

Figure 1 - Giemsa-stained karyotype of Bryconamericus aff. iheringii. cytotype 1 with $12 \mathrm{M}+18 \mathrm{SM}+8 \mathrm{ST}+14 \mathrm{~A}$, cytotype 2 with $10 \mathrm{M}+22 \mathrm{SM}+8 \mathrm{ST}+12 \mathrm{~A}$ and cytotype 3 with $8 \mathrm{M}+28 \mathrm{SM}+$ $6 \mathrm{ST}+10 \mathrm{~A}$. Portela-Castro (1999) suggested that these variations may have been the result of pericentric inversion and that perhaps these cytotypes corresponded to different species of the Bryconamericus genus. The same author also observed $2 \mathrm{n}=52$ in two other Bryconamericus species from the River Ivaí basin (PR) with different karyotypes: Bryconamericus spp. 1 with $4 \mathrm{M}+14 \mathrm{SM}+10 \mathrm{ST}+24 \mathrm{~A}$ and Bryconamericus spp. 2 with $8 \mathrm{M}+20 \mathrm{SM}+8 \mathrm{ST}+16 \mathrm{~A}$.

Portela et al. (1988) found $2 \mathrm{n}=52$ in Bryconamericus stramineus distributed as 26M-SM+26ST-A. Wasko and Galetti Jr. (1998) studied five Bryconamericus species from three Brazilian river basins, which all had $2 \mathrm{n}=52$ chromosomes, except Bryconamericus spp. E from the Avoadeiras Stream (MT) with $2 n=54$. The chromosome formulae found for these species were also different, and the fundamental numbers varied from 88 to 102 .

Although the diploid number of 52 chromosomes is characteristic of Bryconamericus, as previously described, the karyotypes for the different species in this genus vary, suggesting that chromosome rearrangements may be involved in the karyotypic evolution of these groups of fish. The karyotypic structure of the River Agua da Floresta population $(8 \mathrm{M}+22 \mathrm{SM}+10 \mathrm{ST}+12 \mathrm{~A})$ is very similar to the Bryconamericus aff. iheringii cytotype 2 from the River Keller, River Ivaí basin (PR), differing only in the number of metacentric and subtelocentric chromosomes, which
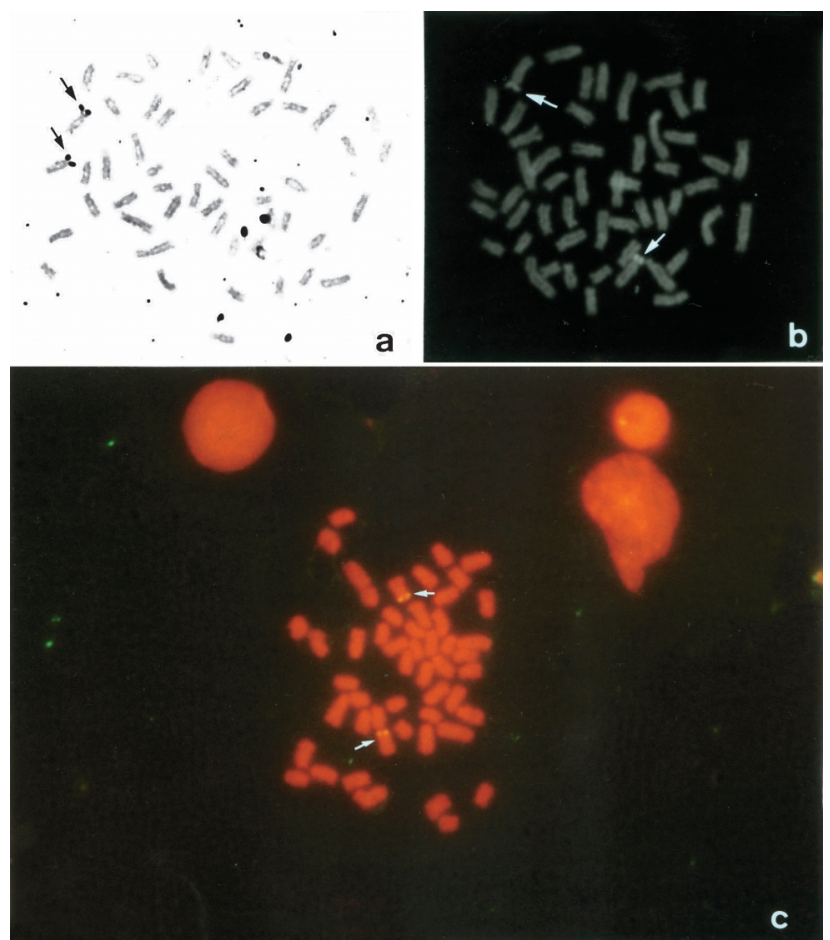

Figure 2 - Differentially stained metaphases of Bryconamericus aff. iheringii. (a) AgNOR staining, (b) $\mathrm{CMA}_{3}$ staining, (c) Fluorescence in situ hybrization with biotin-labeled $18 \mathrm{~S}$ rDNA probe. The arrows show the nucleolar chromosomic pair. 
also suggests that there may have been chromosome rearrangements, probably pericentric inversions, responsible for these differences between the two populations.

NORs were identified in the telomeric region on the short arm of a pair of large-sized submetacentric chromosomes in Bryconamericus aff. iheringii from the River Água da Floresta (PR) (Figure 2a). All studies carried out to date on the Bryconamericus genus have shown multiple NORs for this group. Wasko and Galetti Jr. (1999) observed nine phenotypes, based on the number and localization of NORs in four Bryconamericus species examined, two populations from the River Piracicaba (SP), one population from the Três Bocas Stream (PR) and another from the Avoadeiras Stream (MT). Portela-Castro (1999) studied three species from the River Ivaí basin (PR) and also observed a variation of 2 to 4 nucleolar chromosomes; in spite of this inter- and intraindividual variability, the presence of one pair of large submetacentric chromosomes was relatively constant in two species, Bryconamericus spp. 2 and Bryconamericus aff. iheringii (Cytotypes 1 and 2).

Thus, the Bryconamericus aff. iheringii population investigated in this study is the first of the Bryconamericus genus found to have simple NORs. According to Hsu et al. (1975), species with a single pair of NORs could be considered ancestors of related species whose NORs are distributed among several chromosomes. Therefore, regarding this trait, the Bryconamericus populations studied up to now could be considered more recent compared to the Bryconamericus aff. iheringii population of the River Água da Floresta. In addition, the presence of a pair of large submetacentric chromosomes, as observed in some species from the River Ivaí basin, including Bryconamericus aff. iheringii, would support this hypothesis.

Other genera of the Tetragonopterinae sub-family such as Moenkhausia (Portela, Galetti and Bertollo, 1988), Tetragonopterus and Gymnocorymbus (Alberdi and Fenocchio, 1997) also show simple NORs. However, the multiplicity of NORs is fairly frequent in other genera of this subfamily, mainly Astyanax (Morelli et al. 1983; Mizoguchi and Martins-Santos, 1998; Maistro et al., 2000a, among others).

Treatment with the fluorochrome chromomycin $\mathrm{A}_{3}$ was also used to show NORs because these regions are associated with GC-rich DNA families in some fish species (Pendás et al., 1993). B. aff. iheringii chromosomes studied with this fluorochrome showed agreement between the AgNORs and $\mathrm{CMA}_{3}$ sites detected (Figure $2 b$ ), indicating that the NORs in this species are rich in GC. Portela-Castro (1999) also used $\mathrm{CMA}_{3}$ fluorochrome in different Bryconamericus species and observed sites corresponding to AgNOR sites. Wasko (1996) observed in all the species studied that most of the chromosomes labeled with mitramicine also had AgNORs, except for Bryconamericus spp. E.
Fluorescent in situ hybridization was used with an $18 \mathrm{~S}$ rDNA probe to indicate the location of the ribosomal genes with greater precision. In the metaphases analyzed, the signals appeared on the short arm of a pair of submetacentric chromosomes (Figure 3a), corresponding to results with silver nitrate and $\mathrm{CMA}_{3}$. This is the first study on the Bryconamericus genus where FISH was used to identify the ribosome cistrons. Marco-Ferro et al. (2001) used $18 \mathrm{~S}$ and $5 \mathrm{~S}$ rDNA probes on the Tetragonopterinae subfamily to characterize four Astyanax scabripinnis populations. A probable differential activation of the NORs among the populations was observed with the $18 \mathrm{~S}$ probe and AgNORs, and the 5S probe showed 8 sites in all the populations. This technique has also been used recently in other groups of fish to better characterize NORs, for example in Pinirampus pirinampu (Swarça et al., 1999) and Zungaro zungaro (Swarça et al. 2001b) of the Pimelodidae family, where the $18 \mathrm{~s}$ rDNA probe showed heteromorphisms the size of NORs between homologous chromosomes.

C banding showed a heterochromatic block in the centrometic and telomeric regions in most of the $B$. aff. iheringii chromosomes. The 16, 17, 18, 19 and 20 pairs, all subtelocentric, displayed stronger staining in the telomeric regions (Figure 3A), and can be considered heterochromatic markers in this species. The distribution of heterochromatin is variable in the Bryconamericus genus. Wasko and Galetti Jr. (1998) observed heterochromatic blocks in the interstitial, telomeric and centromeric regions in five Bryconamericus spp. populations, and one of them had at least four entirely heterochromatic arms from different chromosomes. In Bryconamericus aff. iheringii, cytotypes 1 and 2, and Bryconamericus spp. 2 from the River Ivaí basin (PR) investigated by Portela-Castro (1999), the heterochromatic blocks are restricted to the centromeric regions of practically all the chromosomes and also on the short arms of pairs corresponding to those with NOR staining.

Treatment with restriction enzymes has been used to help in chromosome classification for better karyotype determination and also in the study of chromosome polymorphisms. The $A l u \mathrm{I}$ restriction enzyme recognizes and cleaves specific DNA (AG/CT) sequences. The heterochromatic regions resistant to the action of the $A l u \mathrm{I}$ represent regions that have a low frequency of DNA sequences recognized by this enzyme. The treatment with $A l u$ I did not digest the heterochromatic regions of the subtelocentric marker pairs 16, 17, 18, 19 and 20 (Figure 3B) in Bryconamericus aff. iheringii from the River Água da Floresta (PR), indicating that these regions do not possess blocks with sequences rich in $\mathrm{AG} / \mathrm{CT}$. However, in the centromeric regions of the $1,2,3$ and 4 pairs, all metacentric, which are $\mathrm{C}+$ banded, were cleaved by $A l u \mathrm{I}$, showing that the heterochromatin of these regions had a different composition from that found in the telomeric re- 


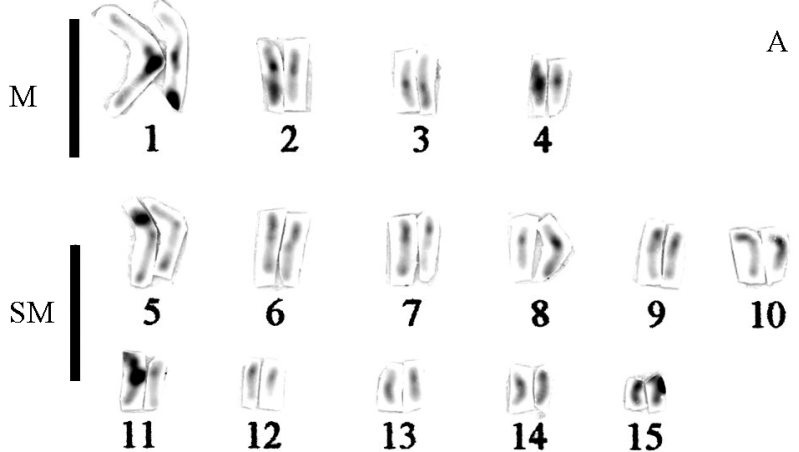

A
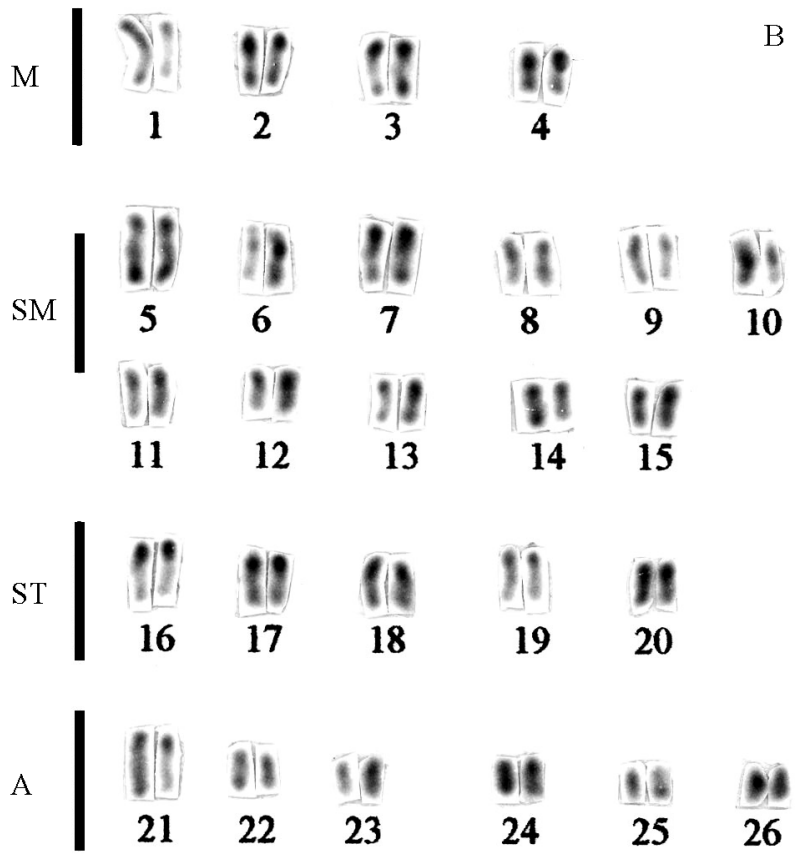

Figure 3 - C-banded karyotype (A) and restriction enzime AluI-treated karyotype (B) of Bryconamericus aff. iheringii.

gions of the 16, 17, 18,19 and 20 pairs. Therefore, the treatment with AluI enzyme associated with $\mathrm{C}$ banding allowed the identification of different types of heterochromatin in the chromosome structure of this Bryconamericus aff. iheringii population.

This is the first study to examine the effect of a restriction enzyme, namely $A l u \mathrm{I}$, on the cytogenetic study of Bryconamericus, and it would be interesting to use this treatment in other species of this genus, for better character- ization of the heterochromatic regions of the chromosomes in these fish.

Souza et al., (1996) observed different types of heterochromatin in Astyanax scabripinnis, with the use of different chromosome banding techniques such as $\mathrm{C}$ banding, $\mathrm{CMA}_{3}$ fluorochrome, mitramicine and DAPI. AluI has also produced a linear differentiation in other groups of fish, similar to that with C banding (Abuín et al., 1994; Bouza, et al., 1994; Maistro et al., 2000b; Swarça et al., 2001a, among others).

The data provided here permit a fairly specific characterization of Bryconamericus aff. iheringii from the River Água da Floresta (PR). This population was shown by different types of chromosome banding to be more conservative compared to the other species studied by other authors, since variation in this population in regard to karyotype or even in the NOR number and localization, which are so common in other Bryconamericus species, was not observed.

\section{Acknowledgments}

The authors are grateful to CAPES for their financial support and to the Dr. Oscar Akio Shibatta, by identifying of the species analysed.

\section{References}

Abuín M, Amaro R and Sanchez L (1994) Improving Salmo salar karyotype: restriction enzyme and replication banding. Cytobios 78:143-152.

Alberdi AJ and Fenocchio A (1997) Karyotypes of five Tetragonopterinae species (Pisces, Characidae) from Argentina. Cytologia 2:171-176.

Almeida-Toledo LF (1985) As regiões organizadoras do nucléolo em peixes. Ciênc Cult 37(suppl):448-453.

Bertollo LAC, Takahashi CS and Moreira-Filho O (1978) Citotaxonomic consideration on Hoplias lacerdae (Pisces, Erytrinidae). Rev Brasil Genet 1:103-120.

Bouza C, Sanchez L and Martínez P (1994) Karyotipic characterization of turbot (Scophthalmus maximus) with conventional fluorochrome and restriction endonuclease. Marine Biology 120:609-613.

Britski HA, Sato Y and Rosa ABS (1988) Manual de identificação de peixes da região de Três Marias (com chave de identificação para os peixes da Bacia do São Francisco). 3rd edition. CODEVASP, Brasil, 115 pp.

Cuadrado A and Jouve N (1994) Mapping and organization of highly-repeated DNA sequences by means of simultaneous and sequential FISH and C-banding in 6x-triticale. Chromosome Res 2:331-338.

Géry J (1977) Characoids of the World. T.F.H. Publications, Inc. Ltda, 672 p.

Heslop-Harrison JS, Schwarzacher T, Anamthaw-Jónsson K, Leitch AR, Shi M and Leitch IJ (1991) In situ hibridization with automated chromosome denaturation. Technique-J Meth Cell Mol Biol 3:109-116. 
Howell WM and Black DA (1980) Controlled silver staining of nucleolos organizer regions with a protective colloidal developer; a one-step method. Experientia 36:1014-1015.

Hsu TC, Spirito SE and Pardue ML (1975) Distribution of the $18+$ $28 \mathrm{~S}$ ribosomal genes in mammalian genomes. Chromosoma 53:25-36

Levan A, Fredga K and Sandberg AA (1964) Nomenclature for centromeric position on chromosome. Hereditas 52:201220.

Marco-Ferro DA de, Néo DM, Moreira-Filho O and Bertollo LAC (2001) Nucleolar organizing regions, $18 \mathrm{~S}$ and $5 \mathrm{~S}$ in Astyanax scabripinnis (Pisces, Characidae): populations distribution and functional diversity. Genetica 110:55-62.

Maistro EL (1996) Caracterização morfológica estrutural de cromossomos supranumerários em peixes. Doctoral Thesis. UNESP, Botucatu, SP, Brasil.

Maistro EL, Oliveira C and Foresti F (2000a) Sympatric occurrence of two cytotypes of Astyanax scabripinnis (Characiformes, Characidae). Genet Mol Biol 23:365-369.

Maistro EL, Oliveira C and Foresti F (2000b) Cytogenetic analysis of A- and B-chromosomes of Prochilodus lineatus (Teleostei, Prochilodontidae) using different restriction enzyme banding and staining methods. Genetica 108:119-125.

Mezzanotte R, Bianchi U, Vanni R and Ferrucci L (1983) Chromatin organization and restriction endonuclease activity on human metaphase chromosomes. Cytogenet Cell Genet 36:562-566.

Mizoguchi SHN and Martins-Santos IC (1998) Activation patterns of nucleolar organizer region in Astyanax scabripinnis populations (Pisces, Characidae). Cytologia 63:259-265.

Morelli S, Bertollo LAC, Foresti F, Moreira-Fiho O and Toledo Filho SA (1983) Cytogenetic considerations on the genus Astyanax (Pisces, characidae). I. Karyotypic variability. Caryologia 36:235-244.

Nelson JS (1994) Fishes of the world. Wiley, USA, 3rd edition, $600 \mathrm{pp}$.

Pendás AM, Morán P and Garcia-Vásquez E (1993) Ribosomal RNA genes are interspesed throughout a heterochromatic chromosome arm in the Atlantic salmon. Cytogenet Cell Genet 63:128-130.
Portela ALBS, Galetti Jr PM and Bertollo LAC (1988) Considerations on the chromosome evolution of Tetragonopterinae (Pisces, Characidae). Rev Bras Genet 11:307-316.

Portela-Castro ALB (1999) Citogenética de Peixes da Subfamília Tetragonopterinae (Pisces, Characidae): Aspectos Citotaxônomicos e Evolutivos. Doctoral Thesis. Universidade Estadual de Maringá, PR, Brasil.

Schmid M (1980) Chromosome banding in Amphibia IV. Differentiation of $\mathrm{G}-\mathrm{C}$ and $\mathrm{A}-\mathrm{T}$ rich chromosome regions in Anura. Chromosoma 77:83-103.

Sumner AT (1972) A simple technique for demonstrating centromeric heterochromatin. Expl Cell Res 75:304-306.

Souza LS, Moreira-Filho O and Galetti Jr PM (1996) Heterochromatin differentiation in the characid fish Astyanax scabripinnis. Braz J Genet 19:405-410.

Swarça AC, Giuliano-Caetano L and Dias AL (1999) Cytogenetic characterization through chromosomic banding of Pinirampus pirinampu (Pisces, Pimelodidae) from the Tibagi river basin PR/Brazil. Caryologia 1-2:31-35.

Swarça AC, Giuliano-Caetano L and Dias AL (2001a) Analyses of nucleolus organizer regions and heterochromatin of Pimelodus maculatus (Pisces, Pimelodidae). Genetica 110:97-100.

Swarça AC, Cestari MM, Giuliano-Caetano L and Dias AL (2001b) Cytogenetic characterization of the large south american siluriform fish species Zungaro zungaro (Pisces, Pimelodidae). Chromosome Science 5:51-55.

Wasko AP (1996) Estudos citogenéticos no gênero Bryconamericus (Pisces, Characidae). Uma abordagem citotaxonômica evolutiva. Masters Thesis. Universidade Federal de São Carlos, SP, Brasil.

Wasko AP, Vênere PC and Galetti Jr PM (1996) Chromosome divergence between two simpratic characid fishes of the genus Bryconamericus. Braz J Genet19:225-230.

Wasko AP and Galetti Jr PM (1998) Karyotype diversity in the neotropical fish Bryconamericus (Characidae, Tetragonopterinae ). Cytobios 94:185-193.

Wasko AP and Galetti Jr PM (1999) Extensive NOR variability in fishes of the genus Bryconamericus (Characidae). Cytologia 64:63-67.

Editor: Yatiyo Yonenaga Yassuda 